\title{
脂肪肝と Xylitol
}

\section{—-Xylitol の Lipolytic Effect について—.}

\author{
木村篤人*
}

\section{緒言}

オロット酸 (orotic acid, OA) は，20 世紀初頭に初 ぬて牛乳中で発見されで以来，人乳を含む数種の乳汁

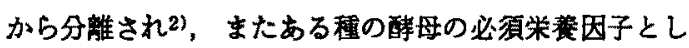
て知られていた有機酸でる゙!。1948 年 Novak ら4は， ネズミの成長促進因子をアルコール蒸留廃液中に発見し てビタミン $\mathbf{B}_{13}$ と名づけたが，その後紫外吸収特性や 生物学的活性から既知の OA との類仪性が指摘された5). さらに牧野6)，Manna王怯それぞれ OA が子獣の発充 を促進することを明らかにした。

他方では OA が pyrimidine nucleotide 生成の precursor として重要な中間体であることが明らかにさ れ8ー11)，また OA 自身の生合成機序が解明されてき た12).この上ろにして OA の生物学的役割が明らかに なるに及んで OA に細胞再生の促進効果, 細胞壊死の 防止効果が期待されて，肝疾患の治療剂として実験的あ るいは臨床的な検討が加えられるよ5になり，Noelle13)， Beckmann 5 (4), 吉田 $5^{(5)}$ ，山形ら $\left.{ }^{16}\right)$ にっって慢性肝矨 患に対する治療勃果が報告され，旰治療薬郕として OA は広く臨床的に注目されるようになった。

ところか: 1955 年, Standerfer, Handler ら ${ }^{17)} は ， O A$ の幼若ラットに対する発育成長效果の dose response を 検討中，OAの投与量が增すにしたがって肝脂質量が增 加することを瀷め，OA の経口投与によって脂肪旰が発 症することを明らがした，1960 年 Handschumacher ら 18,19 ) $4 ， 1 \%$ OA を混合した合成飼料で飼育した ラットに発症する脂肪肝が， $0.25 \%$ K adenine sulfate を飼料に添加することによって発庭が抑制されることを 認めた。

1959 年高橋, 藤沢ら2014，黄変米力ピによる実験的 慢性肝障害に対して種々の肝趾護剂の薬剤斺果を比較検

\footnotetext{
*A. Kimura:東京慈恵会医科大学 第1 内科(主任教授 : 高 㰌忠雄).
}

討中，たまたま OA の投与によって肝の線維化が強く 促進され，さらに 4-amino-5-imidazole carboxamide (AICA) が線維化を抑制する事実を見出し，にわかに OA 脂肪肝に対する関心を高め, 以後著者の 教室では OA 脂肪肝の発生機序を肝内 nucleotide の代謝との関 連から解明しようとして研究を続けてきた。すなわち adenine sulfate18,19)中 AICA21) の添加C OA 脂肪肝の 発症が抑制されたといら報告を基喽として，各種の ribonucleotide 関連物質を飼料中の OA K対して $1 / 10$ モル比に添加して、ラットを飼育して抗脂所作用を比較 检討したところ，表1に示すごとく purine 系列で塩 基部分にのみ諗められ, nucleoside nucleotide では

表 1. OA 脂肪䀒に対する nucleotides おょび関 連物賈の抗脂肝作用

\begin{tabular}{|c|c|c|c|}
\hline & Bases & Nucleosides & Nucleotides \\
\hline \multirow{4}{*}{ Purine } & Adenine (H) & \multirow{4}{*}{$\begin{array}{l}\text { Adenosine } \\
(-) \\
\text { Inosine }(-)\end{array}$} & \multirow{4}{*}{$\begin{array}{l}\text { AMP(-) } \\
\text { IMP (-) } \\
\text { Succinyl- } \\
\text { AICA- } \\
\text { ribotide (-) }\end{array}$} \\
\hline & 4-Amino-5- & & \\
\hline & $\begin{array}{l}\text { Imidazole } \\
\text { carboxamide } \\
\text { (AICA)(H) }\end{array}$ & & \\
\hline & $\begin{array}{l}\text { Hypoxanth- } \\
\text { ine }(+)\end{array}$ & & \\
\hline \multirow{3}{*}{$\begin{array}{l}\text { Pyrimidine } \\
\text { series }\end{array}$} & Uracil(-) & \multirow[t]{3}{*}{ Uridine (-) } & $\operatorname{CMP}(H)$ \\
\hline & Cytosine (-) & & UMP(-) \\
\hline & Thymine (-) & & $\begin{array}{l}\text { CDP- } \\
\text { choline (-) }\end{array}$ \\
\hline
\end{tabular}

明らかな作用は認められずこれに反して pyrimisine 系列では cytidine-5'-monophosphate (CMP) にのみ強 い抗脂肝作用が認められた 22,23?.

これらの事実は，OA 脂肪肝の発症に purine と pyrimidine nucleotides 間の metabolic unbalance $\rightarrow$ 関与することを示し，藤沢 ${ }^{24)}$, 長村25)恃肝酸溶性 nucleotides の分析から，OA 脂肪所で uracil nucleotides の著しい蓄㽮と adenine nucleotides $\$$ cytosine nucle- 


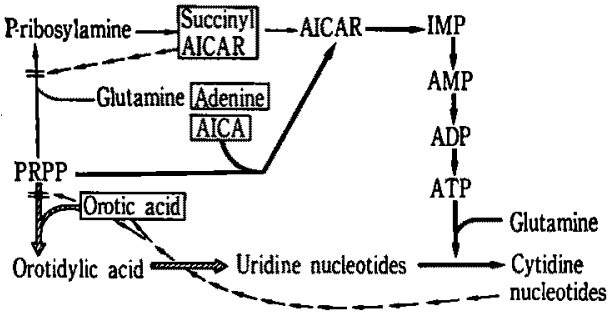

図 1, 肝に括ける purine 执よび pyrimidine nucleotide 生合成に括计る feedback control

otides の著減を認めた. そして purine 塩基にみられ る抗脂肝効果は, purine 塩基が OA その phosphoribosyl pyrophosphate (PRPP) のせり合いに勝って, purine nucleotide 生成への salvage 合成系が賦活され， 同時に orotidylic acid を経る pyrimidine nucleotides の de novo の合成系への PRPP 利用が揤制されるので 出万5と推定した（図 1). Phosphoribosyl pyrophosphate (PRPP) は purine および pyrimidine 塩基と直接 反応して ribonucleotide を生合成するので, nucleotide 生合成の rate limiting step は PRPP の生成にあり, しかも de novo $の$ purine nucleotide 生合成への PRPP の利用は，PRPP 自身の合成速度と pyrimidine ribonucleotide pyrophosphorylase 反応への PRPP の利用 速度によって䂓正されていると考えられる。そこで肝に おける PRPP の合成あるいは供給を高めることができ れば，OA 脂肪肝にみられる nucleotide 間の metabolic unbalance は是正され，脂肪肝の発症を抑制することが できるはずである.

このような肝における PRPP の供給をたかめる物質 として，著者は uron 酸回路の中間体である xylitol に 注目した. Uron 酸回路仗 glucose $\longrightarrow$ glucuronic acid $\longrightarrow$ i-xylulose-xylitol を経て NAD-xylitol (D-xylulose) dehydrogenase によって xylitol は D-xylulose に変換し,つけて D-xylulose kinase によって D-xylulose 5-phosphate となり,ここで uron 酸回路は五炭糖 燐酸回路に接続して，図 2 のごとくD-ribulose 5-phóphate $\longrightarrow$ ribose 5-phosphate を経て PRPP を生成し26, 27) nucleotide 合成系に連なる藤沢，高橋ら28)はすでに xylitol の経口投与が，正常ラット肝の uron 酸回路, 五炭樯橉酸回路を次々と賦活することを enzyme level の検討から明ら加し，さらに $1 \%$ OA 飼料に $5 \sim 10$ \%の xylitol を添加してラットを飼育した場合, 脂肪肝 の発症が完全に抑制されることを観察した299.

本論文では，予防実験，治療実験を通じて脂肪肝に及

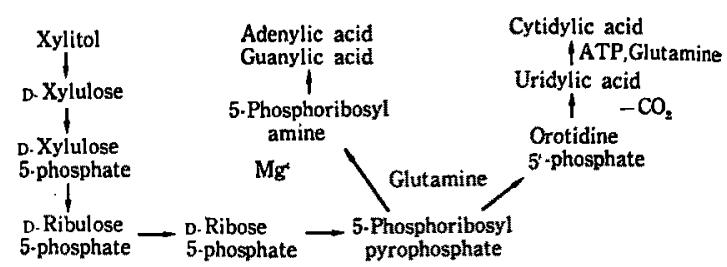

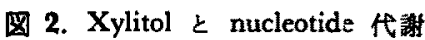

隹す xylitol の脂肝抑制効果を脂質代謝，核酸代謝の面 からくわしく検討して, xylitol $の$ lipolytic effect $の$ 本 態を中心に OA 脂肪肝自体の成因の解析を試み，脂肪 肝発症機序の一つとして肝内 nucleotides $の$ metabolic unbalance を重視し，さらに脂肪朋治療につながる問 題点について論述するものである。

\section{実䖪方法}

\section{1. 実験的物と姛料}

実験動物は Wistar 系雄ラットて体重 $150 \mathrm{~g}$ 前後の ઠのを用いた．飼料は Handschumacher の報告にした がった合成飼料 30 )を基礎飼料とし，これに $1 \%$ の割合 にOAを添加したものを OA 飼料，基整飼料の 5〜10 \%を xylitol でおきかえたるのを xylitol 飼料，さらに xylitol 飼料に $1 \%$ に OA を添加したるのを OA-xylitol 飼料とし，各飼料は体重 $100 \mathrm{~g}$ あたり 1 日 $15 \mathrm{~g} を$ 投与した.

\section{2. 实験条件}

これらの各ラット群をそれそれれ基整食対照群， xylitol 食対照群 (xylitol 群), OA-xylitol 食群 (OA-xylitol 群）とよび、はじめから OA-xylitol 飼料で飼有した群 は xylitol 予防群，また OA 飼料て飼青して脂肪肝発 症後に OA-xylitol 飼料にきりかえた群は xylitol 治療 群として，すべて 16 時間緦食ののちに実験に供した。

可及的すみやかにとりたした肝颌は，肝門部から生理 的食塩水て灌流して十分肝内の血液を洗洛したのち种量 し，酸溶部をさけて切り出し，1）脂質の分析に $1 \mathrm{~g} ， 2 ）$ 酸溶性 nucleotide の分析に $2 \mathrm{~g} ， 3$ ) 醉素活性の測定に $\lg$ ，4）肝細胞分画に $2 \mathrm{~g}$ ，さらに一部を電顕的㭘索に 用いた。

標識 xylitol の肝脂質, 肝酸溶性 nucleotide 分画への とりこみをみる実験では，6時間緦食後 C14-xylitol 50 $\mu \mathrm{c}$ を腹腔内に投与して 2 時間後実験に供した。 なお本

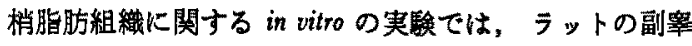
丸脂肪組織 $2 \mathrm{~g}$ について観察した。 


\section{3. 生化学的測定法}

肝脂質の分析 : 肝脂質は肝湿重量の 10 倍容の chloroform 2: methanol $1(\mathrm{v} / \mathrm{v})$ 混液て $37^{\circ} \mathrm{C} 60$ 分抽出し, 抽出沪液をさらに0.2 容の生理的食塩水と振洞して 1 夜 放置後, chloroform 層を窒素気流中で濃縮乾固して重 量を測定して肝総脂質量とした．この総脂質を $10 \mathrm{ml} の$ ether に溶解して一定量となし，その上清を各脂翼分画 の定量に用いた. Triglyceride の定量には末広法31を用 い, phospholipid は Fiske, Sabbarow 法 ${ }^{32)}$ に従って脂 質燐を定量し、これに 25 を乗じたすのを phospholipid 量とした. Cholesterol の定量は Kiliani 反志を用いた 柴田法33)に従って総 cholesterol t定量した.

旰脂質の分画化は薄層クロマトグラフィーにより，固 定相にシリカゲル，展開液に石油エーテル，エーテル，

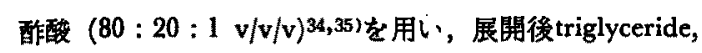
phospholipid に相当する部分をけずりとり，chloroform, methanol (2:1) 湿液て 3 回抽出し，それぞれの分析に 用いた。

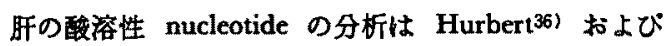

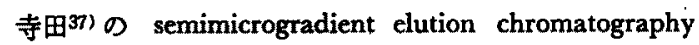
に準じて，凍結肝 $2 \mathrm{~g} の 0.6 \mathrm{~N}$ 過塩素酸抽出液を $5 \mathrm{~N}$ 菏性力リ溶液て中和して得た酸溶性分画抽出液を $0.6 \times$ $40 \mathrm{~cm}$ の Dowex $1(\times 10)$ キ酸型カラムで分画化した. なおこれらの訮脂質分画中酸溶性分画中の xylitol-14C の放射活性の測定は，各分画の一部をプランチエット にとり直接 gas flow counter で測定するか，むるいは thin layer chromatoscanner (Aloca, Model TRM 1-B) によった.

畈酳素活性の測定 : 肝 triglyceride lipase 活性の測定 は Olson, Aloupovic の方法38)に準じ, 0.1M phosphate buffer ( $\mathrm{pH}$ 7.2) て 10 倍の肝 homogenate をつ くり，12,000×g 10 分間遠心してその上清を醉素液と し, $1 \mathrm{ml}$ の醅素液に $7 \mathrm{ml}$ の $0.1 M$ phosphate buffer (pH 7.2), $1 \mathrm{ml}$ の $4 \%$ sodium deoxycholate, $1.0 \mathrm{ml}$ の $10 \%$ olive oil emulsion ( $2 \%$ のアラビアコムと $10 \%$ のオリーブ油を含さ水溶液を homogenize したるの) を加え, $37^{\circ} \mathrm{C} て$ incubate し遊離する脂肪酸を Trout らの変法39)で測定した. 䀒 esterase 活性は Hesterin の 変法40)に準 $L$, 旰 $\lg$ に $0.03 M$ phosphate buffer (pH 7.4) $5 \mathrm{~m} l$ を加之て homogenize $L, 12,000 \times \mathrm{g}, 10$ 分 間遠心してその上清を醅素液とし， $1 \mathrm{ml}$ の酵素液を 0.9 $\mathrm{ml}$ の $0.03 M$ phosphate buffer (pH 7.4) および 0.1 $\mathrm{m} l の$ methyl butyrate $の$ ethanol 溶液 (methyl butyrate
$100 \mu \mathrm{mol}$ を含む) を加えて 30 分 incubate したのち， 水 $4 \mathrm{~m} l$ を加えて上く混和し，この溶液 $0.5 \mathrm{~m} l$ にアル カリ性ヒドロキシラミン $1.5 \mathrm{ml}$ を加えて室温で 5 分放 置後, $18 \%$ TCA $1 \mathrm{ml}, 4 \mathrm{~N} \mathrm{HCl} \mathrm{lm} l$ おび $10 \% \mathrm{FeCl}_{3}$ 溶液 $1 \mathrm{~m} l$ を順次加えて混合し遠心して，その上清につ いて $530 \mathrm{~m} \mu$ の吸光度を測定した。

肝細胞分画化: $0.25 M$ sucrose 溶液て肝の 10 倍 homogenate をつくり, Schneider, Hogeboon 法41ににし たがって $0^{\circ} \mathrm{C}$ の冷却下で分画化した.

肝 mitochondria の脂助酸酸化能の測定 : Chelderin, Beinert ら42) の方法にしたがって $1.5 \mathrm{ml}$ の mitochondria 想濁液に $4 \mu \mathrm{mol} の \mathrm{MgCl}_{2}, 3 \mu M$ の adenine 5'-phosphate, $20 \mu M$ の phosphate buffer (pH 7.2), sparker として $5 \mu M$ の citrate, 基質として $20 \mu M$ の sodium octanate を加え, $0.9 \% \mathrm{KCl}$ て最終容積か 3.0 $\mathrm{m} l$ になるように調製し，酸素をガス相として $37^{\circ} \mathrm{C} て ゙$ manometric $に \mathrm{O}_{2}$ uptake を测定し，基質を加えない

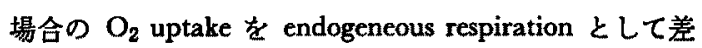
し引き, $\mathrm{O}_{2}$ uptake $(\mu l)$ を mitochondria の乾燥重量で 除して $\mathrm{QO}_{2}$ とした. 反応終了後, 反応液に $0.2 \mathrm{ml}$ の $60 \%$ 過塩素酸を加え，生ずる沈殿をのぞき，上清の一 部について Edson の aniline citrate 法43)でアセト酶酸 を定量した。

末梢脂肪組織の lipolysis については Kappeler の方 法44に準じ, $750 \mathrm{mg}$ の脱脂 bovine albumin を含む Krebs Ringer bicarbonate 溶液 $100 \mathrm{ml} k$ glucose また はxylitol をそれぞれ $100 \mathrm{mg}$ 溶解した溶液をつくり， それぞれその $20 \mathrm{~m} l$ 中で正常ラットの副等丸脂肪組織

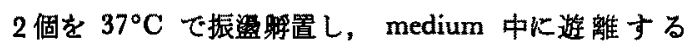
glycerol 量を 30 分ごとに Eggstein, Kreutz の方法45) で定量した.

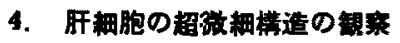

細切した肝組織を水冷 $1.1 \%$ glutaraldehyde, $0.1 M$ phosphate buffer ( $\mathrm{pH} 7.4$ ) 中て 2 時間固定して, さら に $2 \%$ osmium tetraoxide, $0.21 M$ sucrose, $0.1 M$ phosphate buffer にて 2 時間固定して得た標本を Porter 型 超ミクロトーム $\left(\mathrm{MT}_{2}\right)$ により薄切し, uranylacetate 圭 よび lead citrateで 2 重染色を施し，HV 11 DS 型電 子顕微鏡にて直接 $1.0 \times 10^{4}$ て観察した。

\section{成績ならびに考察}

\section{OA 脂肺肝に対する Xylitol の抗㴯汗作用}

1) Xylitol の脂肪肝予防効果 


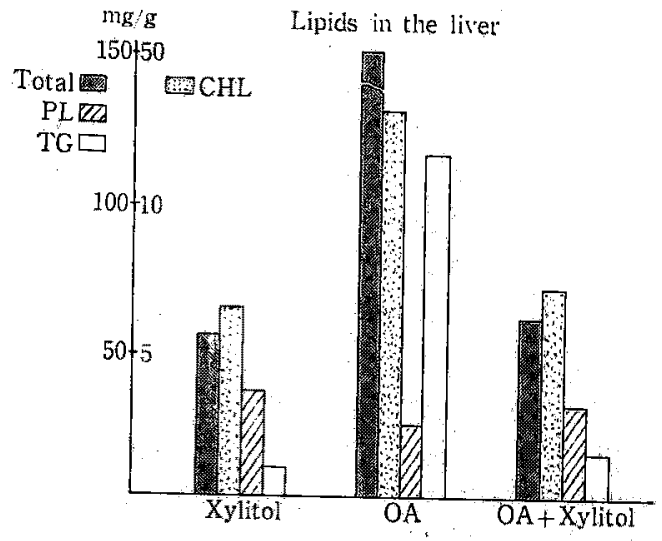

図 3. 肝脂質最の変化

Wistar 系雄ラットを OA 飼料で飼育すると，2 週間 以内に肝小葉の周辺部からはじまる著明な脂肪肝が急速 に発症するのであるが，OA-xylitol 飼料でラットを 2 週間飼育した場合には，脂肪肝の発症は潘とんぞ完全に 抑制された。すすなわち，両群の肝脂質量の相異を xylitol 食群を対照として比較すると，図3のごとく 群の肝にみられた著明な triglyceride の蓄積は OAxylitol 群では完全に抑制された。

腹腔内に投与された tracer dosis の C14-xylitol の一 部は, 肝の triglyceride そ phospholipid の glycerol 部 分に incorforate されるので, xylitol の抗脂肝作用を

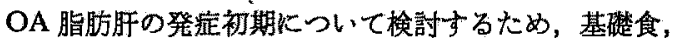
xylitol 食, OA 食, OA-xylitol 食でそれぞれラットを 5 日間飼育し，6時間䋽食後 $50 \mu \mathrm{c} の{ }^{14} \mathrm{C}$-xylitol 腹 腔内に投与して，2時間後実駼に供して肝脂暨を抽出し て, 薄層クロマトグラフィーで triglyceride, phospholipid, cholesterol, free fatty acid を分離して，各分画 の放射活性を thin layer chromatoscanner て測定して triglyceride そ phospholipid 分画への放射活性の分布を 各群についてみると，表2のごとく，OA 群にみられる

表 2. 肝脂質分画に於ける Xylitol-14C の分布

\begin{tabular}{|c|c|c|}
\hline & Triglyceride & Phospholipid \\
\hline Purified diet & $26.5 \%$ & $72.6 \%$ \\
\hline $\begin{array}{l}\text { Purified diet }+ \\
\text { Xylitol }\end{array}$ & 27.6 & 70.2 \\
\hline Orotic acid diet & 60.9 & 37.6 \\
\hline $\begin{array}{l}\text { Orotic acid diet } \\
+ \text { Xylitol }\end{array}$ & 19.2 & 80.7 \\
\hline
\end{tabular}

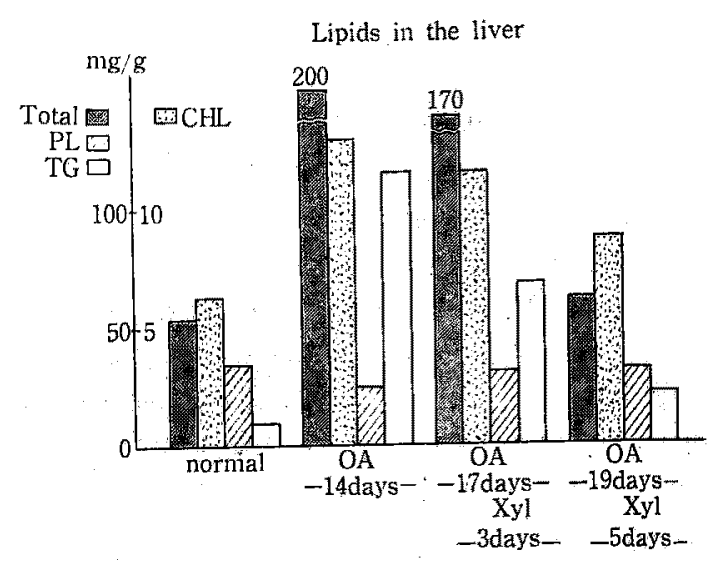

図 4. 完成した $\mathrm{OA}$ 脂肪肝に対与を xylitol の治 療效果と肝内脂實

triglyceride 分画での放射活性の著減は OA-xylitol 群で は这転していることが観察された，このことは xylitol が脂肪肝に执ける phospholipid 合成能を元進して，

tiglycerideの蓄積を抑制することを示睃する事実である。

2) Xylitol の脂肪肝治潦效果

ラットK OA 飼料を 2 㗐間投与して脂肪肝が完成し たのるに飼料を OA-xylitol 食にきりか无ると, 図40 ごとく，OA 投与群にみられた著しい肺 triglyceride の 蓄積はきわめて短期間に急速に消失していく，この経過 を組織学的にみると，完成した脂肪訮ては肝小葉の全域 に著しい脂肪浸潤が認められるのでるが(図 5-a)、こ の時期に OA 飼料に xylitol z $10 \%$ k添加して， 3 日後には脂肪浸潤は小葉中心方告速消失していく状 態が認められた（図 5-b).

\section{Xylitol $の$ lipolytic effect $\emptyset$ 本態}

1) 脂肪肝 $の$ nucleotide pattern $\&$ xylitol

$\mathrm{C}^{14-x y l i t o l} 50 \mu \mathrm{c}$ をラットの腹腔内に投与して，2時 間後の肝酸溶性分画の nucleotide pattern $亡$ xyiltol-14C の分有を，OA 脂肪肝お上び xylitol 治蟟肝 (OA 食飼 料で 2 週間飼育後，OA-xylitol 飼料で飼育 5 日後のラ ット肝）について比較すると，图6-a に示すごとく， OA 脂肪肝にみられる adenine, cytosine nucleotide $の$ 減少之 uracil nucleotide の增加とい, 5 特異な nucleotide pattern と各 nucleotide 放射活牲の低下は，図6b のごとくxylitol 治療 5 日で明らが歌善され，しか \&ylitol-14C $\rightleftarrows$ purine, pyrimidine nucleotice の全分 画へ著しくとりこまれた。

2）肝脂質の動態と xylitol 


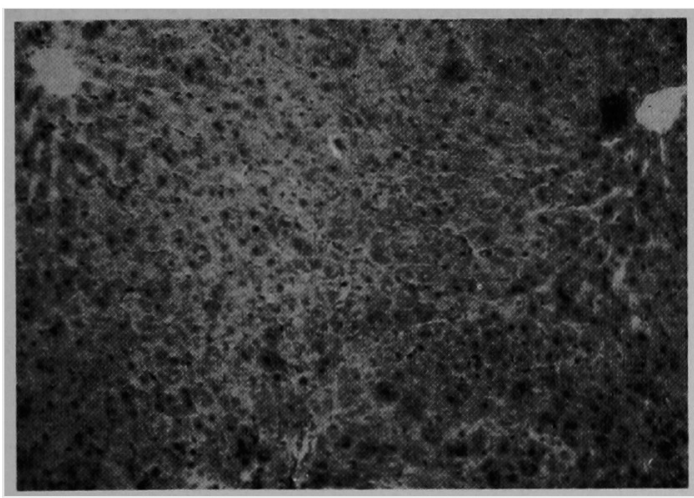

a. OA 脂肪肝 (OA 閏料て 16 日間铜育したラット 䀒)

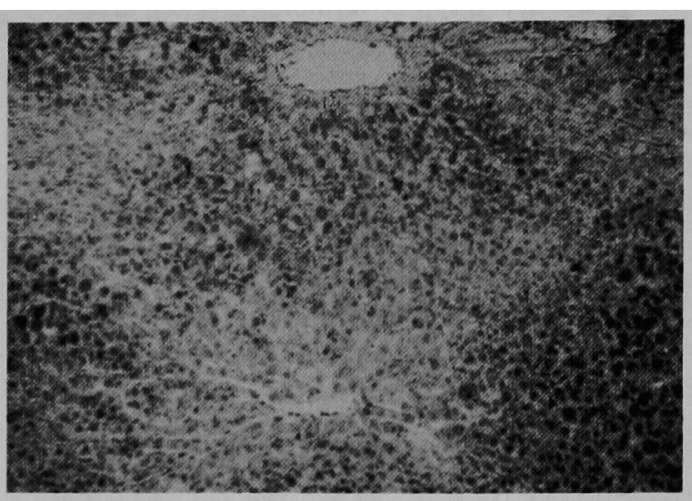

b. Xylitol 治療肝 (OA で 14 日間铜热し以後 OA+ xylitol 食で 3 日間铜育したラット旰)

国 5. OA 脂肪肝と xylitol 治㙩效果

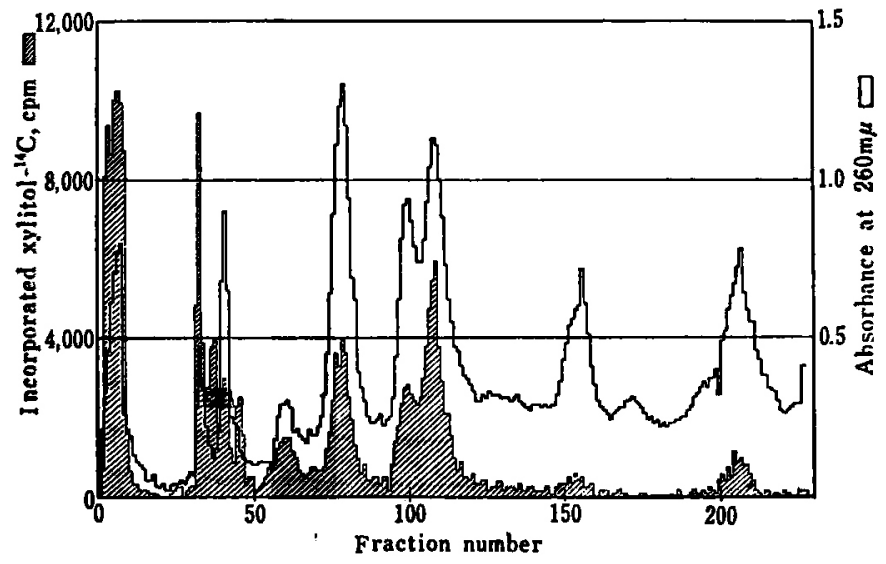

a. Chromatographic profile of acid-soluble nucleotides in the rat liver, fed on an orotic acid diet for 19 days

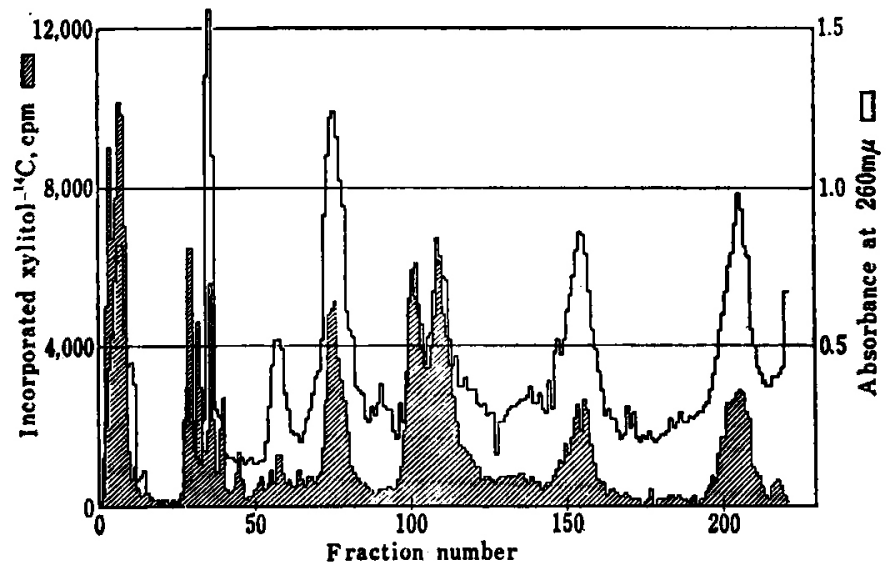

b. Chromatographic profile of acid-soluble nucleotides in the rat liver, fed on an orotic acid diet for 19 days and xylitol for the last 5 days

国 6. 
$13: 572$

訮

表 3. OA 脂肪肝と Xylitol 治燎肝の肝脂留

a. 肝脂筫量の変化

$\mathrm{mg} / \mathrm{g}$ wet tissue

TG

PL

Purified diet

12.1

33.7

Orotic acid diet

109.0

29.1

Orotic acid +Xylitol

14.1

30.4

b. 肝脂貿分画の㪟射活珄の分布

TG PL CHL NEFA

\begin{tabular}{|lllll|}
\hline †Purified diet & $47.3 \%$ & $43.3 \%$ & $0 \%$ & $2.0 \%$ \\
†Orotic acid diet & 69.5 & 21.2 & 0 & 3.2 \\
*Orotic acid +Xylitol & 32.4 & 66.1 & 0 & 1.9 \\
\hline
\end{tabular}

†Rats were fed for 14 days

* Rats were fed on orotic acid diet for 19 days, treated with xylitol for the last 5 days

基礎食群, OA 食群，xylitol 治源群の 3 群について の肝脂質の動態をみると，OA 脂肪肝では常に triglyceride の著しい蓄積と同時に phospholipid の減少が認 められ, xylitol 治療訮では绿は正常域にまで改善を示 す (表 3-a). 巳らに tracer dosis の C14-xylitol (50 $\mu \mathrm{c})$ を腹腔内投与後，2時間に括ける肝脂質分画へのとりこ みを比較すると，表 3-b にみるごとく，基礎食群では， triglyceride と phospholipid には约均等に放射活性が 分布するのに反し，OA 群では triglyceride 分画に 69 . 5\%のとりこみを謬め, phospholipid 分画では 21.2\% と放射活性の分布の低下を㷵めた. Xylitol 治療群ではこ の関係は逆転し, triglyceride 分画へのとりこみは 32.4 \%と减少し, phospholipid 分画へのとりこみは $66.1 \%$ と高值を示し，先の予防奏験にみられた成績と同粎の結 果を得た。

以上の実験結果は，OA 脂肪肝に対する xylitol の lipolytic effect の本態について, xylitol が肝における nucleotide unbalance 正常化しつつ，肝の橉脂質合 成系を賦活する可能性をかなり明白に裹つけるるのであ 万5.

3) Xylitol $の$ lipolytic effect 機序についてて

表 4 は肝脂質にとりこまれた traser dosis の xylitol${ }^{14} \mathrm{C}$ の経時的消長を示し，OA 脂肪肝では脂質の turnover が著しく低下するのに反して，xylitol 治療わずか 3 日間で肝脂質の turnover が著しく高まって，はは対 照の速度にまで回復した。このよ5な turnover rateの 差異を肝の triglyceride lipase あるいは esterase 活性の 相異に求めて检討を試みたのであるか，図7に示すごと
13 巻10号 (1972)

表 4. 腹腔内に投与した Xylitol-14C $(50 \mu \mathrm{C})$ の肝脂 貿における turn over

\begin{tabular}{|c|c|c|c|}
\hline & \multicolumn{3}{|c|}{$\begin{array}{l}\text { cpm/gm wet liver after } \\
\text { intraperitoneal injection } \\
2 \mathrm{hrs} \text {. 16hrs. } 185 \mathrm{hrs} .\end{array}$} \\
\hline Purified diet for 17 days & 103,500 & 25,500 & 9,150 \\
\hline $\begin{array}{l}\text { Purified diet, } 17 \text { days }+ \\
\quad \text { Xylitol for last } 3 \text { days }\end{array}$ & 87,500 & 27,300 & 5,800 \\
\hline OA diet for 17 days & 150,000 & 81,350 & $36,9 \cap 0$ \\
\hline $\begin{array}{l}\text { OA diet, } 17 \text { days }+ \\
\text { Xylitol for last } 3 \text { days }\end{array}$ & 153,000 & 41,550 & 6,550 \\
\hline
\end{tabular}

$$
\begin{aligned}
& \mathrm{CH}_{2}-\mathrm{O}-\stackrel{\mathrm{C}}{\mathrm{C}}-\mathrm{R}_{1} \quad \stackrel{\mathrm{O}}{\mathrm{R}}-\stackrel{\mathrm{C}}{\mathrm{C}}-\mathrm{OH} \quad \mathrm{CH}_{2}-\mathrm{OH} \\
& \text { CH-O-C }-\mathrm{R}_{2} \frac{\text { TG.Lipase }}{+3 \mathrm{H} \rho} \mathrm{R}_{2}-\mathrm{O}_{\mathrm{O}}-\mathrm{OH}+\mathrm{CH}-\mathrm{OH} \\
& \mathrm{CH}_{2}-\mathrm{O}-\stackrel{\mathrm{C}}{\mathrm{C}}-\mathrm{R}_{2}+\mathrm{R}_{1}-\stackrel{\mathrm{C}}{\mathrm{C}}-\mathrm{OH} \quad \mathrm{CH}_{2} \cdot \mathrm{OH}
\end{aligned}
$$

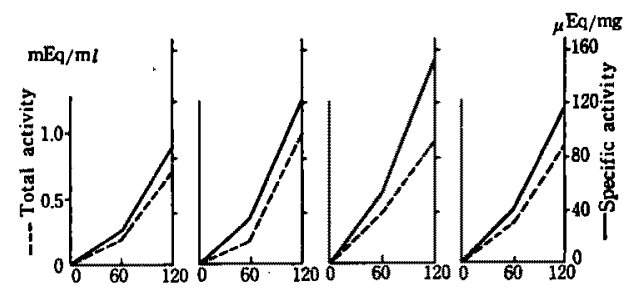

$$
\begin{aligned}
& \text { Purified diet Purified diet Orotic acid diet Orotic acid diet } \\
& \text { for } 3 \text { weeks for } 3 \text { weeks for } 3 \text { weeks for } 3 \text { weeks } \\
& \text { and Xylitol for } \\
& \begin{array}{ll}
\text { the last } 1 \text { week } & \text { and Xylitol for } \\
\text { the last } 1 \text { week }
\end{array}
\end{aligned}
$$

a. 遊離脂肪酸量からみた䏕 triglyceride lipase 活生
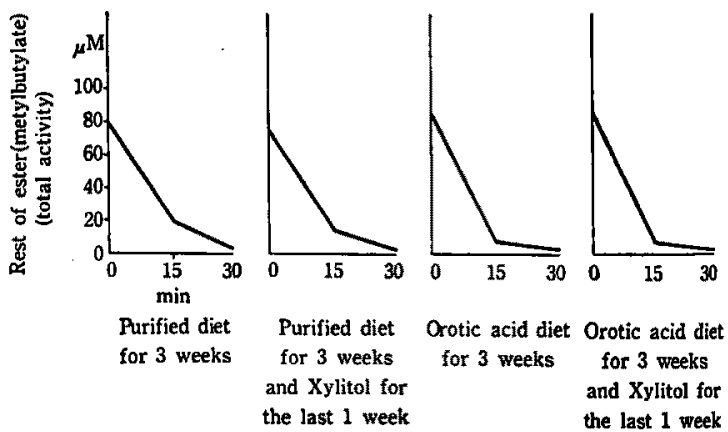

Purified diet for 3 weeks the last 1 week

Orotic acid diet Orotic acid diet for 3 weeks for 3 weeks and Xylitol for the last 1 week

b. 肝の esterase 活性

图 7.

く，基礎食群，xylitol群，OA 群，OA-xylitol 治療群の 間にはとんど有意の差が認められなかった．したがって 肝にさかんに嘲肪が蓄積している場合す，また xylitol 添加によって訮蓄皘脂肪が急速にとれていく場合も， triglyceride $の$ glycerol と脂肪酸への分解はは怔同じ速 
表 5. 肝 Mitochondria 脂肪酸酸化能に及ぼす Xylitol の影整

\begin{tabular}{|c|c|c|c|}
\hline & $\begin{array}{l}\mathrm{O}_{2} \\
\text { uptake, } \\
\mu l\end{array}$ & $\begin{array}{l}\text { Dry welght } \\
\text { (mg) of liver } \\
\text { mitochondria }\end{array}$ & $\mathrm{QO}_{2}$ \\
\hline Purified diet for $4 \mathrm{~W}$ & 119.0 & 33.7 & 3.54 \\
\hline \multicolumn{4}{|l|}{ Purified diet for $4 \mathrm{~W}$} \\
\hline Xylitol for last 2 D & 142.0 & 31.7 & 4.48 \\
\hline Orotic acid diet $(4 \mathrm{~W})$ & 65.0 & 33.3 & 1.95 \\
\hline \multicolumn{4}{|l|}{ Orotic acid diet (4W) } \\
\hline Xylitol for last $2 \mathrm{D}$ & 346.0 & 30.5 & 11.35 \\
\hline
\end{tabular}

Mitochondrial suspension, $1.5 \mathrm{ml}$ made to final volume of $3.0 \mathrm{ml}$ with $0.9 \% \mathrm{KCl}$ containing $3 \mu$ moles of AMP, $4 \mu$ moles of $\mathrm{MgCl}_{2}, 20 \mu$ moles of phosphate buffer, $\mathrm{pH} 7.2$, and $20 \mu$ moles of sodium octanate. $5 \mu$-moles of citrate were added as a sparker. Gas phase was oxygen and the temperature was $37^{\circ} \mathrm{C}$.

度で進んでいることになる。

次に脂肪酸酸化の場である肝 mitochondria 分画につ $い て$, octanate を基として manometric に脂肪酸酸 化能の動態を检討した．表 5 に示すごとく，OA 脂肪䀒 では脂肪酸酸化能が著しい低下を示したのであるが， xylitol 添加 2 日後にはこの酸化能は著しく促進された. 同時にこれらの肝について subcellular fraction の燐脂 質の分布を比較したところ，表 6 のごとく，OA 脂肪肝 の mitochondria 分画にのみ有意な燐脂質量の低下が認 められ, xylitol 添加で急速に正常レベルに戻ることが 観察された。

表 6. 䀒飞却ける燐脂筫の Subcellular localization

\begin{tabular}{lrrrr}
\hline & N & Mt & Mc & S \\
\hline Purified diet & 43.6 & 100.5 & 159.5 & 1.2 \\
Purified diet $+X y l i t o l$ & 42.3 & 94.8 & 150.0 & 1.0 \\
Orotic acid diet & 44.2 & 58.5 & 158.8 & 2.8 \\
Orotic acid diet +Xylitol & 44.2 & 82.0 & 149.9 & 1.7 \\
\hline & & $\mu \mathrm{g} / \mathrm{mg}$ & dry weight
\end{tabular}

$\mathrm{N}$ : nucleus $\mathrm{Mt}$ : mitochondria

Mc: microsome S: soluble fraction

このようにして, xylitol は脂肪肝の mitochondria に おける脂肪酸䣼化能を著しく促進することが明らかにな ったのであるが，この過程で旰内にアセト酶酸の蓄積を 伴うか否かは ketosis 発症の可能性につながる問題とし て重要である，そこで mitochondria の脂肪酸酸化能を
表 7. 䀒 Mitochondria の脂肪酸化能おょび acetoacetate 生成に及畹子 Xylitol の影辢

\begin{tabular}{|c|c|c|}
\hline & $\mathrm{Qo}_{2}$ & Acetoacetate \\
\hline Purified diet for 17 days & 4.36 & $15.8 \mu \mathrm{g} / \mathrm{m} l$ \\
\hline $\begin{array}{l}\text { Purified diet, } 17 \text { days, } \\
\quad \text { xylitol for last } 3 \text { days }\end{array}$ & 5.66 & 17.8 \\
\hline OA diet for 17 days & 0.91 & 4.5 \\
\hline $\begin{array}{l}\text { OA diet, } 17 \text { days, } \\
\text { xylitol for last } 3 \text { days }\end{array}$ & 15.20 & 10.2 \\
\hline
\end{tabular}

manometricに測定した反応液中のアセト酰酸量をEdson 法で検討したところ，表 7に示すごとく, xylitol 治療肝 では脂肪酸酸化の著しい六進が認められたのにるかかわ らず，アセト酢酸量は対照に比してむしろ低值を示した。 このことは xylitol が脂肪酸の完全酸化を促進すること を示晙するすのであって，磄尿病における xylitol の antiketogenic な臨床効果 $46 \sim 48)$ と考え合わせて興味ある 実験結果と考える。

以上の生化学的観察から,OA 脂肪肝の本態は,肝にお ける燐脂蜇合成の障害, ことに肝細胞 mitochondria の 膜様構造における撛脂質量の低下による脂肪酸酸化の障 害に基つく triglyceride の蓄積に帰せられ，また xylitol $の$ lipolytic effect の本態はこのような脂肪旰 mitochondria の質的・機能的久損の正常化にあることが明らか になったのであるが，さらに形態学的な售付けを得るた めに, 肝の mitochondria の population を中心に電顕 的な観察を試みた。

図 8-a は xylitol 添加基溇食 2 週の対照肝の電顕像 で，超微構造的に正常であるが，図 8-bの OA 脂肪肝 では的細胞内に脂肪滴の著しい浸潤が謵められるとと もに, bizarr shape の mitochondria が出現し, その population は明らかに著减を示し，同時に粗面小胞体 は層状配列を失って不規則な配列を示し，vesicular configuration が目立つ. OA 飼料に xylitol を添加すると, 図 8-c のごとく肝細胞内の脂肪滴は急速に消失すると ともに mitochondria の population は増して, 粗面小 胞体の規則正しい、層状配列が復元されていく.

以上の実験的観察は，脂肪肝に対する xylitol の lipolytic effect についてなされたるのであるが，本来 lipolysis とは脂肪組織について問題となる言葉であって， triglyceride の醅素的加水分解によって脂肪酸と glycerol を生成する現象と定義されている．したがって，脂 肪組織の liposis に対して xylitol がぞのように作用する 


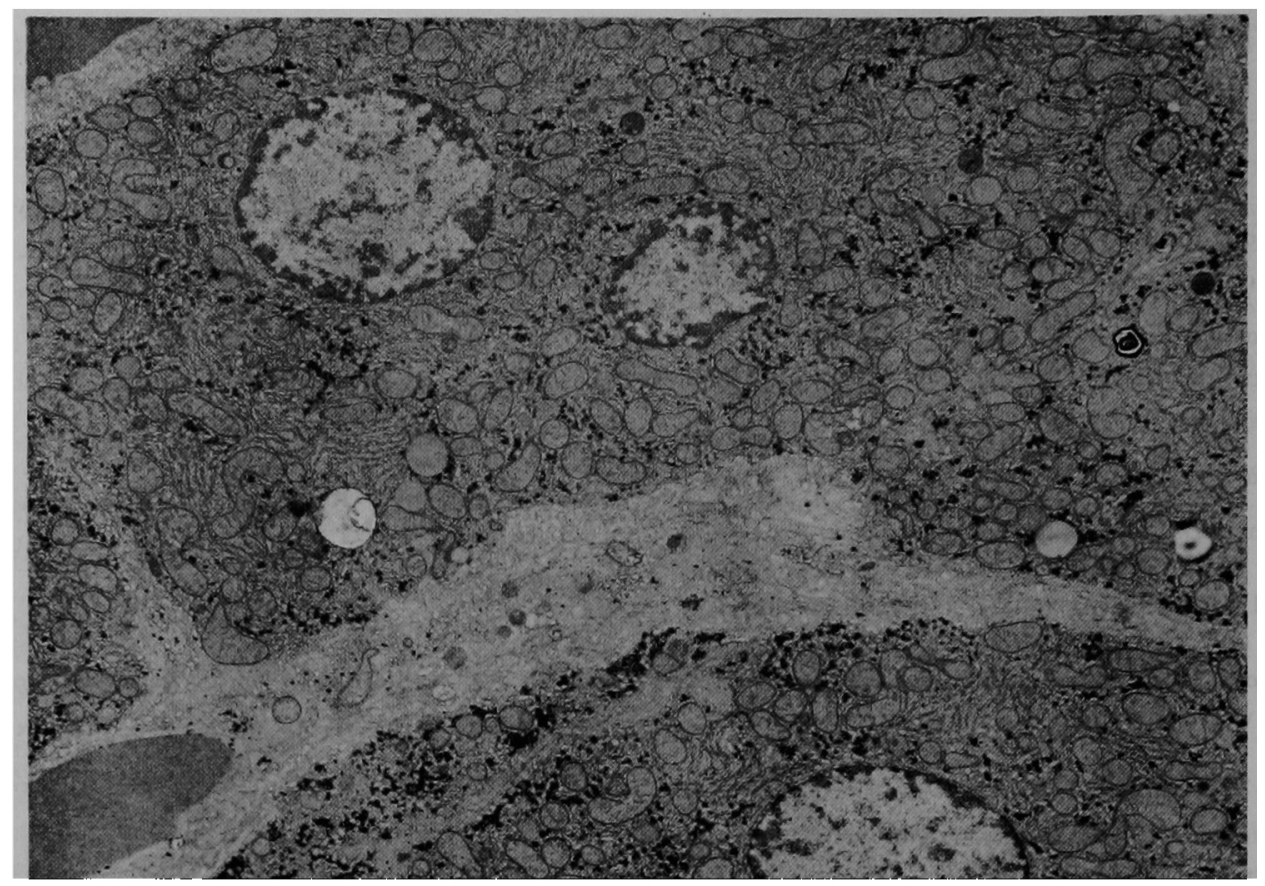

因 8-a. 基隄令で的育し最後の 3 日間に xylitol を添加したラット肝の㫣影像

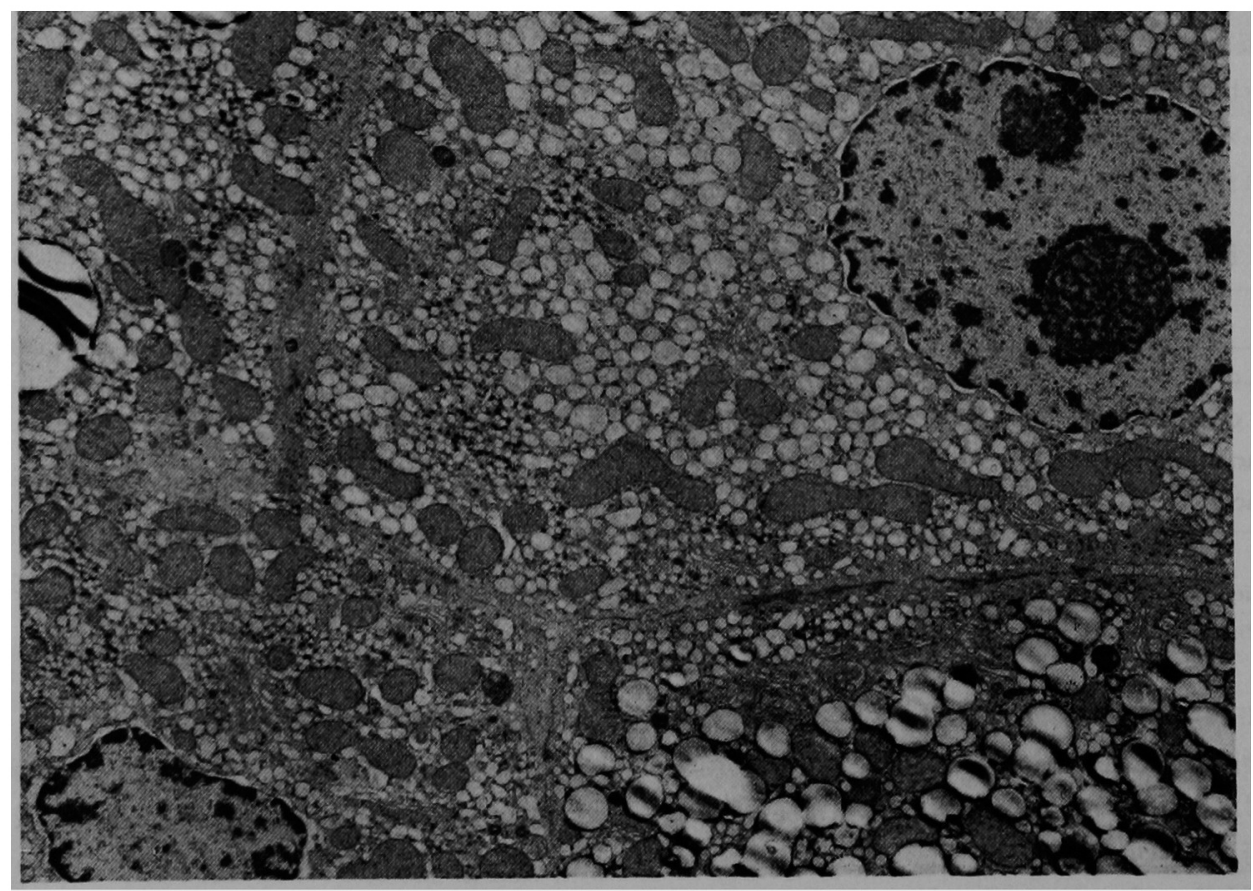

図 8-b. OA 脂肝の電影像 


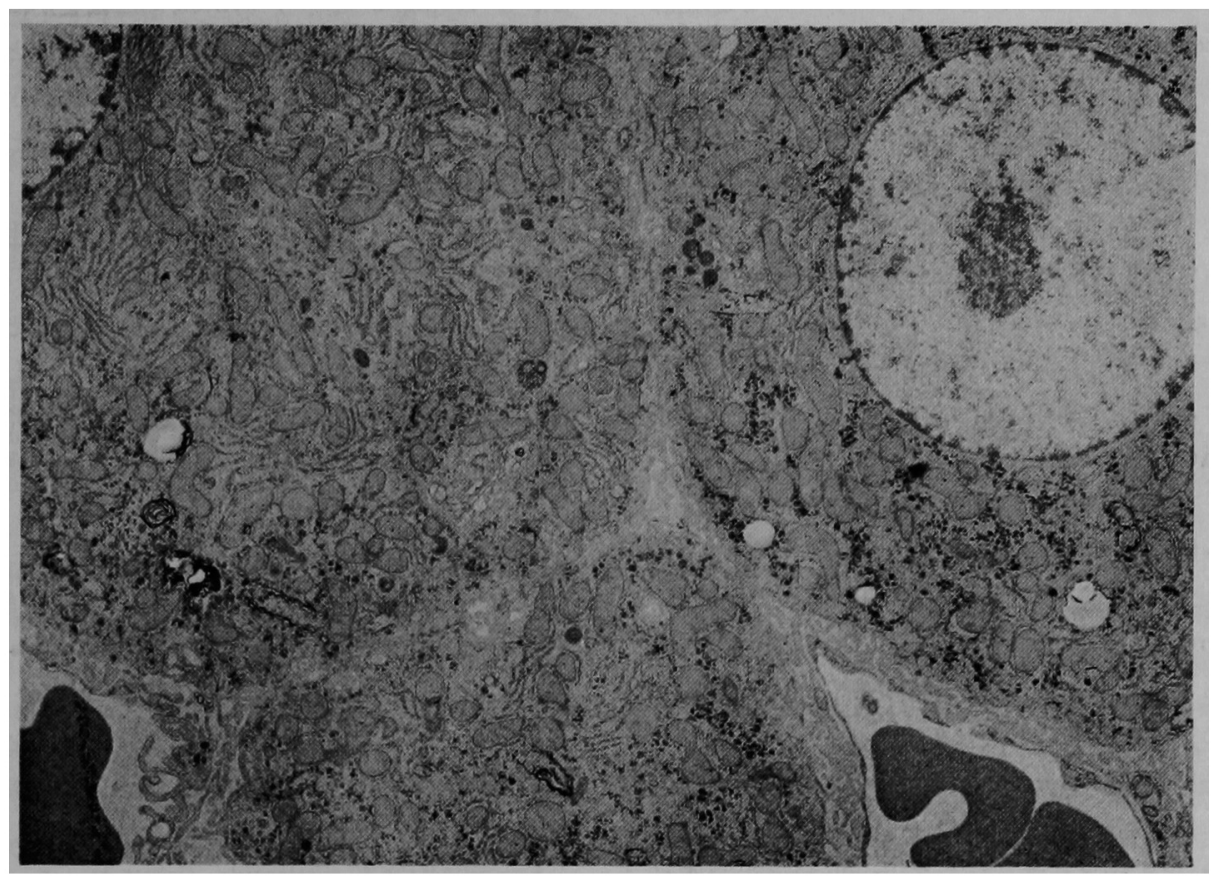

図 8-c. OA-xylitol 治療 10 日目のラット肝电顕像

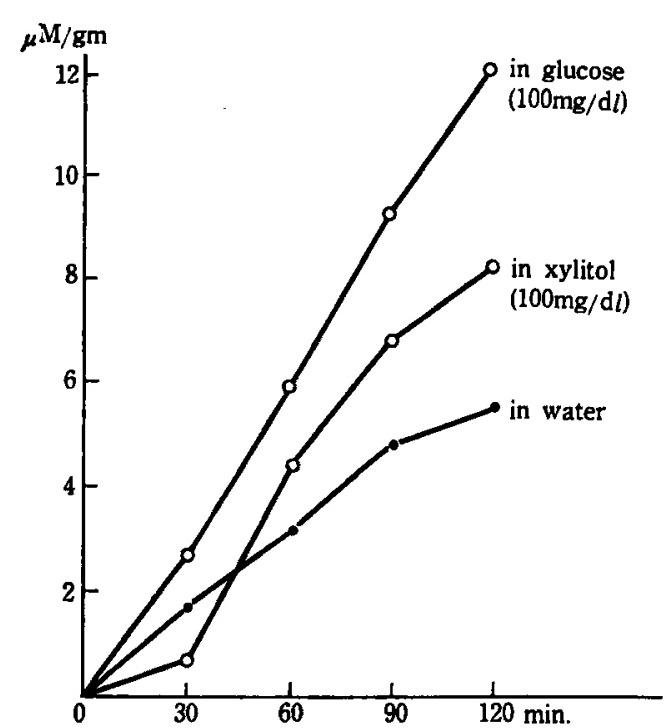

a. 副率丸脂肪組彎の glycerol 故出に及はす xylitol の野 (in vitro)

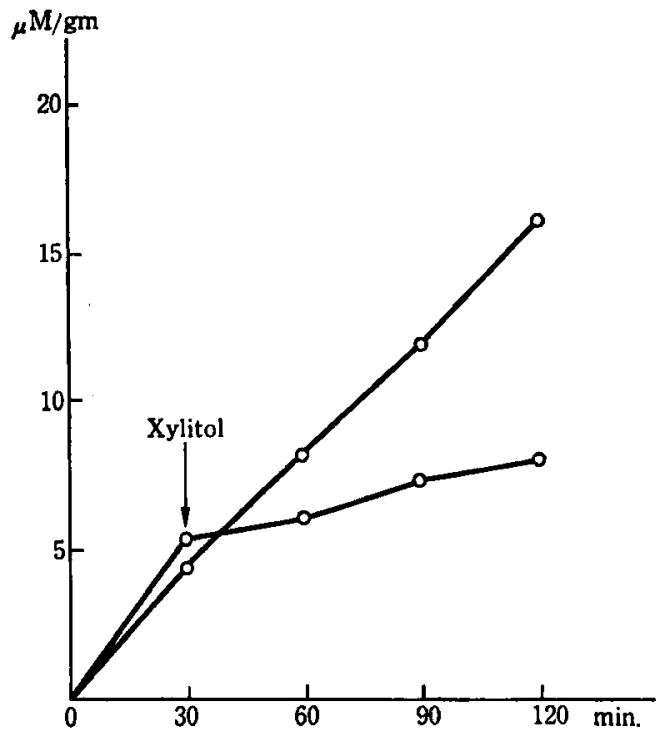

b. Glucose medium 中で副睪丸脂肪組轼の glycerol 故出に対する xylitol の影整 (in vitro)

图 9. 
$13: 576$

肝

かる検討されねばならない、そこで albumin を遊離脂 肪酸の acceptor として, in vitroで副輁丸脂肪組 縕を glucose $100 \mathrm{mg} / \mathrm{d} l$ 添加 Krebs Ringer bicarbonate 中で incubate した場合と, 同濃度の xylitol 存在下で incubate した場合に，medium 中に遊離する glycerol を経 時的に湘定して比較すると，図 9-a のごとく xylitol 添加によって脂肪組織の lipolysis は明らかに㧕制され た. また glucose medium 中て lipolysis の進行中に xylitol を添加してる，図 9-b のごとく lipolysis は著 しく低下することが認められた。

脂肪組穖の lipolysis て生成される遊離脂肪酸と glycerol 5ち, 遊離脂肪酸の大部分は脂肪組蟣の 1-2-glycerophosphate として再エステル化され，さらに triglyceride として脂肪組繀中へとりこまれるのであるが， 遊離 glycerol は glycerokinase を欠く脂肪組織では再 利用されることはほとんどないので49,50)，glycerol 量は lipolysis の正確な物さしとなりえよう.

一般に脂肪組緎の lipolysis は glucose の供給と密接 に相関し，脂肪組織が glucose と十分利用し 5 る状態て は lipolysis は抑制されて，むしろ triglyceride 合成が たかまる. Glucose 利用の低下している状態一一飢餓や 糖尿病一てては lipolysis は元進して, 遊離脂肪酸は肝 蔵，筋肉等の組織に達して酸化基質としての需要をみた 才51). 脂肪組織には hormone sensitive lipase が存在 $L$, いわゆる lipolytic hormone としては ACTH52), 成長 ホルモン53), epinephrine ${ }^{54)}$, norepinephrine ${ }^{55,56), ~ g l u c-~}$ agon ${ }^{57)}$ などが知られている. Insulin は逆に脂肪組 織 の lipolysis を㧕制する58)。 脂肪組織の triglyceride lipase を活性化し, lipolysis 促進すると考えられ，脂斿組織に対する glucagon の lipolytic effect は adenylcyclase 系を刺激して, 脂肪組 蟣の cyclic 3',5'-AMP level をたかめるためと考え ら れている59,60).

Insulin は細胞内の cyclic-3', 5'-AMP level を下げ るため triglyceride lipase を不活性化に保ち，したが って lipolysis ははとんどみられなくなる61,62). 一方， 脂肪組織の lipolysis を抑制する非ホルモン物質として は, nicotinic acic 63), 2-deoxy-D-glucose ${ }^{63)}$, adenosine $e^{44)}$, adenine nucl sotided4)などが知られている.

Xylitol が glucose に比して in vitro で脂肪組織の lipolysis を低下せしめたことは, xylitol が insulin independent に細胞内にとりこまれ，glucose に比しては るかに利用されやすい䌅質である可能性を示唆している。
13 巻 10 号 (1972)

しかし $100 \mathrm{mg} / \mathrm{d} l$ とい 5 xylitol 湴度はいかにも非生理 的な濃度であって，基買レペルで拮抗阻害とす考えら れ xylitol 添加量の哈味を試みるべきであろうが, 臨床 的に xylitol が血中の脂肪酸レベルを低下させる事実 48)を説明し5る理由の一つであろう。

Uron 酸回路の要員としての xylitol は，生物学的活 性物質として少なくとも2面の作用をるら，1）肝内 nucleotide 代謝相では PRPP 生成刺激物質としてOA 脂肪訮に対しては強い lipolytic effect を示し，2）一 方, 末梢脂肪組織では lipolysis を㧕制する非ホルモン 物質としての效果を示すことはきわめて興味深い。

\section{結語}

以上 OA 脂肪肝の発生機序につい:て，核酸代謝と 脂質代謝の関連から分析を行い，さらK uron 醉 cycle の member である五炭榶アルコール xylitol の経口投 与による OA 脂肪肝発症過程に及ほす影響を検討し， その lipolytic effectについて检討を加え次の結論を得 た.

1. 肝における nucleotide 代謝において xylitol は ribose-5-phosphate を経る PRPP 供与体として, OA 脂肪肔ラットの purine nucleotide $の$ de novo 合成系 を活性化することにより, 胙にむける purine と pyrimidne nucleotide $の$ metabolic unbalance を改善す 万.

2. OA 脂肪肝における xylitol の lipolytic effect の本態は, 1) ATP 関与の CDP-choline, CDP-ethanol amine を介する phospholipid 合成系を賦活化し, 2) 脂肪肝の mitochondria 膜の構成煒脂質量の低下を 是正することによって，3） mitochondria の脂酸酸化 能を著しく元進するといら代謝的な sequential potency にあるのであって，肝の triglyceride lipase あるいは, 非特異的な esterase 活性を介する lipolytic action ては ない４４このよ5な脂肪肝に対する xylitol の効果は 超徽形態的にも証明された５）しかしながら，xylitol は末梢脂肪組織では lipolysis を抑制する。

本稿を終わるにあたりここ指革，ご校閱を䦪わった， 恩師高橋忠雄教授，ならびに終始直接ご指透いただいた 前沢洌講師に澡く感謝するとともにご協力いただいた 本学病理学教室安田宽基助教授，および当教室第 3 研究 室の都兄に深甚の謝意を表す。

なお本論文の要旨は，V. Sessio Soc. Int. Hepatolog- 
icae (I.A.S.L.), Prag Karlsbad, 1968. 第 3 回日本肝满 学会東部会 1969 ，第 55 回日本消化器病学会総会 1969 にて発表した.

また本研究の一部注交部省科学研究貫(高橋忠雄教授)

に負 うところ大であり，さらに xylitol-14C の提供をい ただいた株式会社エーザイのご好意に深謝する。

文 献 1) Biscaro, G. \& Belloni, E.: Ann. Soc. Chim. Milano, 11, 18: 71, 1905. 2) Bendich, A.: The Nucleic Acids, edited by Chargoff, E. \& Davidson, J. N., Vol. 1, Academic Press, Inc., New York, 1955, p. 81. 3) Wieland, O. P., Avener, J., Boggiono, E. M., Bohonos, N., Hatchings, B. L. \& Williams, J. H.: J. Biol. Chem. 186: 737, 1950.4 4) Novak, A. F. \& Hause, S. M.: J. Biol. Chem. 174: 235, 1948. 5) Wright, L. D.: J. Am. Chem. Soc. 72: 2312, 1950.

6) 牧野堅，佐滕精夫，木下武夫，佐々木位：ビタ そ > 6: 605, 1953. 7) Manna, L. \& Hauge, S. M.: J. Biol. Chem. 202: 91, $1953 . \quad$ 8) Wright, L. D., Miller, C. S., Skeggs, H. R., Huff, J. W., Weed, L. L. \& Wilson, D. W.: J. Am. Chem. Soc. 73: 1898, 1951. 9) Weed, L. L. \& Cohen, S. S.: J. Biol. Chem. 192: 693, 1951. 10) Weed, L. L. \& Wilson, D. W.: J. Biol. Chem. 189: 435, 1951.

11) Hurlbert, R. E. \& Potter, V.: J. Biol. Chem. 209: 1, 1954. 12) Reichard, P. \& Lagerkrist, U.: Acta. Chem. Scand. 7: 1207, $1953 . \quad 13)$ Noelle, R.: Dtsch. Med. Wschr. 79: $1331,1953 . \quad$ 14) Beckmann, K., Brügel, H. \& Mertz, D. P.: Dtsch. Med. Wschr. 81: 572, 1956. 15) 吉田常雄, 永井清保, 富 田炤夫, 松久博: 第 45 回日本消化器病学会 1959. 日 消会誌 57: 902， 1960.

16) 山形啟一, 海藤勇和: 最近医学 15: 432, 1960. 17) Standerfer, S. B. \& Handler, P.: Proc. Soc. Exper. Biol. Med. 90: 270, 1955. 18) Handschumacher, R. E., Creasy, W. A., Jaffe, J. J., Pasternack, C. A. \& Hankin, L.: Proc. Natl. Acad. Sci. U. S. 46: 178, 1960. 19) Handschumacher, R. E., Creacy, W. A. \& Hankin, L.: Federation Proc. 19: 310, 1960.20$)$ 高橋忠雄, 茷沢洌はか: 算 3 回国際旰獚研究会日本支部総会, 1961 .

21）山村婎一: 第 1 回 AICA 研究会, 1962. 22) 田 中照二：日内会藉 52: 40, 1964.23$)$ 阙部和产: 慈 医読 80: 890, 1965. 24) Fujisawa, K., Osamura,
H., Kurihara, N., Okabe, K., Tanaka, T. \& Takahashi, T.: Nucleic Acid in Normal and Cancer Tissues, Gann Monograph 6, Maruzen Co., Tokyo, 1968, p. 143.

25）長村日出夫：意医誌 83: 25, 1968.

26) Goldthwait, D. A., Peabsdy, R. A. \& Greenbery, G. R.: J. Biol. Chem. 221: 569, 1956. 27) Kornberg, A., Lieberman, I. \& Simms, E. S.: J. Biol. Chem. 215: 389, 1955 . 28) Fujisawz, K, Ohkawa, K., Tanaka, T. \& Takahashi, T.: International Symposium on Metabolism, Physiology and Clinical Use of Pentoses and Pentitols, edited by Horecker, B. L., Lang, K. \& Takagi, Y., Springer Verlay, Berlin, Heiderberg, New York, 1969, p. $303 . \quad 29)$ Fujisawa, K. \& Takahashi, T.: 5th International Meeting of International Association for the Study of the Liver, Karlovy Vary, Czechoslovakia, July 14, 1968. 30) Handschumacher, R. E., Cresy, W. A., Hankin, L., Jaffe, J. J. \& Pasternak, C. A.: Proc. Natl. Acad. Sci. U. S. 46: 178, 1960.

31) 末広雅也: 生化学 33:387, 1961. 32) Fiske, C. H. \& Sabbarow, Y.: J. Biol. Chem. 66: 375, 1925. 33) 柴田進, 長谷川錦三郎: 医学々敏生物学 39: 1956, p. 21 34) Schlierf, G. \& Wood, P.: J. Lipid. Res. 6: 317 , 1965. 35) Blank, M. L., Schmidt, J. A. \& Privett, O. S.: J. Am. Oil Chemists Soc. 41: 371, 1964.

36) Hurbert, R. B., Schmitz, H., Brumm, A. F. \& Potter, V. R.: J. Biol. Chem. 209: 23, $1954 . \quad 37)$ 寺 田新一：生化学 31: 795, 1959. 38) Olson, A. C. \& Alaupovic, P.: Biochim. Biophys. Acta. 125: 185, 1966.

39) Trout, D. L., Estes, E. H. Jr. \& Friedberg, S. J.: J. Lipid Res. 1: 199, 1960.40$)$ Robert, P. S.: J. Biol. Chem. 232: 285, 1958.

41) Schneider, W. C. \& Hogeboon, G. H.: J. Biol. Chem. 183: $123,1950 . \quad$ 42) Cheldelin, V. H. \& Beinert, H.: Biochim. Bicphys. Acta. 9: 661, $1952 . \quad 43$ ) Edson, N. L.: Biochem. J. 29 : 2082, 1935. 44) Kappeler, H.: Diabetolcgia 2: 52, $19 € 6 . \quad 54)$ Eggstein, M. \& Kreutz, F. H.: Klin. Wschr. 44 (5): 262, 1966.

46) Bässler, K. H. \& Dreiss, G.: Klin. Wschr. 41 :

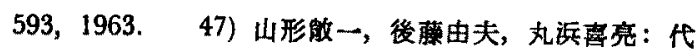
謝 2: 410, 1965.48$)$ Yamagata, S., Goto, Y., Ohneda, A. \& Anzai, M.: Lancet II: 918, 1965. 49) Leboeuf, B.: Handbook of Physiology, edited by Renold, A. E. \& Cakill, G. F., Section 5, Adipose tissue 
American Physiological Society, Washington, D. C. 1965, p. 385 . 50) Vaughan, M.: J. Biol. Chem. 237: 3354, 1962.

51) Frederikson, D. S. \& Gordon, R. S.: Physiol. Rev. 38: 585, 1958 . 52) White, J. E. \& Engel, F. L.: J. Clin. Invest. 37: 1556, $1958 . \quad$ 53) Raben, M. S. \& Hollenberg, C. H.: J. Clin. Invest. 37: 922, 1958. 54) Jungas, R. L. \& Ball, E. G.: Biochemistry 2: 383, 1963. 55) Eaton, R. P.: Proc. Soc. Explt. Biol. Med. 114: 599, 1963.

56) White, J. E. \& Engel, F. L.: Proc. Soc. Exper. Biol. Med. 99: 375, 1958. 57) Vaugham, M., Berger, J. E. \& Steinberg, D.: J. Biol. Chem. 239: 401,
1964. 58) Froesch, E. R., Buergi, H., Bally, P. R. \& Lebhart, A.: Mol. Pharmacology 1: 280, 1965. 59) Rizach, M.: J. Biol. Chem. 239: 392, $1964 . \quad 60$ ) Sutherland, E. W., Butcher, R. W., Robinson, G. A. \& Hardman, J. G.: Wirkungsmechanismen der Hormone, 18 Colloqu. Ges. Physiol. Chem., Mosbach 1967, P. 1, ed, by Karlson, P. Berlin-Heiderberg- New York: Springer 1967.

61) Butcher, R. W., Sneyd, J. G. T., Park, C. R. \& Sutherland, E. W.: J. Biol. Chem. 241: 1651, 1966. 62) Jungas, R. L.: Proc. Nat. Acad. Sci. (Wash.) 56: 757, 1966. 63) Carlson, L. A.: Ann. New York Acad. Sci. 131: 119, 1965. 